九州大学学術情報リポジトリ

Kyushu University Institutional Repository

\title{
Preparation of Anti-dinitrotoluene Polyclonal Antibody and Effect of the Hapten Spacer Length in Coating Antigen on Immunoassay Sensitivity
}

Nagatomo, Kazutaka

Laboratory of Food Analysis, Division of Food Biotechnology, Department of Bioscience and Biotechnology, Graduate School of Bioresource and Bioenvironmental Sciences, Kyushu University

Matsumoto, Kiyoshi

Laboratory of Food Analysis, Division of Food Biotechnology, Department of Bioscience and Biotechnology, Graduate School of Bioresource and Bioenvironmental Sciences, Kyushu University

Ishitobi, Sachiko

Laboratory of Food Analysis, Division of Food Biotechnology, Department of Bioscience and Biotechnology, Graduate School of Bioresource and Bioenvironmental Sciences, Kyushu University

Koga, Mao

Laboratory of Food Analysis, Division of Food Biotechnology, Department of Bioscience and Biotechnology, Graduate School of Bioresource and Bioenvironmental Sciences, Kyushu University

他

https://doi.org/10.5109/14054

出版情報：九州大学大学院農学研究院紀要. 54 (1)，pp. 165-171，2009-02-27. Faculty of Agriculture, Kyushu University

バージョン：

権利関係 : 


\title{
Preparation of Anti-dinitrotoluene Polyclonal Antibody and Effect of the Hapten Spacer Length in Coating Antigen on Immunoassay Sensitivity
}

\author{
Kazutaka NAGATOMO ${ }^{1}$, Kiyoshi MATSUMOTO*, Sachiko ISHITOBI ${ }^{1}$, \\ Mao KOGA ${ }^{1}$, Kiyoshi TOKO ${ }^{2}$ and Norio MIURA ${ }^{3}$
}

\author{
Laboratory of Food Analysis, Division of Food Biotechnology, Department of \\ Bioscience and Biotechnology, Faculty of Agriculture, \\ Kyushu University, Fukuoka 812-8581, Japan \\ (Received October 28, 2008 and accepted December 5, 2008)
}

\begin{abstract}
A polyclonal antibody against 2,4-dinitrotoluene (2,4-DNT) has been raised in rabbit, and the antibody was used to detect 2,4-DNT using an enzyme-linked immunosorbent assay (ELISA) method. A 2,4-dinitrophenyl-keyhole limpet hemocyanine (DNPh-KLH) conjugate was injected into a rabbit, and a polyclonal anti-DNPh-KLH antibody was realized after purification of the serum using protein G column. Aspects of the anti-DNPh-KLH antibody to various nitroaromatic compounds, such as cross-reactivities and avidity, were characterized. The temperature dependence of the avidity between the anti-DNPh-KLH antibody and 2,4-DNT was also evaluated. The quantification of 2,4-DNT was based on the principle of indirect competitive ELISA, in which the immunoreaction between the coating antigen-protein conjugates and the antiDNPh-KLH antibody were inhibited in the presence of free 2,4-DNT in solution. The detection was performed using alkaline phosphatase-labeled anti-rabbit IgG with $p$-nitrophenylphosphate as a substrate. The addition of a mixture of free 2,4-DNT to the anti-DNPh-KLH antibody was found to decrease the absorbance at $405 \mathrm{~nm}$ due to the competitive effect of 2,4-DNT. The effect of the structure of the coating antigen-protein conjugate on the competition of free 2,4-DNT or coating antigen toward anti-DNPh-KLH antibody was also investigated. The immunoassay exhibited excellent sensitivity for the detection of $2,4-\mathrm{DNT}$ in the concentration range of $1 \mathrm{ng} \mathrm{mL}^{-1}$ to $10 \mu \mathrm{g} \mathrm{mL}^{-1}$.
\end{abstract}

\section{INTRODUCTION}

Environmental pollution of soil, river water, and underground water by explosive-related compounds is a serious problem in the areas of buried landmines and/or landmine factories (Hilmi et al., 1999). These compounds are suspected to have human toxicity, mutagenicity, and carcinogenicity (Kennel et al., 2000; Sayama et al., 1998; Tchounwou et al., 2001; Banerjee et al., 1999). Therefore, there is a pressing need to determine the concentrations and distributions of these compounds in the environment. The main component of landmines is 2,4,6-trinitrotoluene (TNT). TNT released into the environment is decomposed and converted to dinitrotoluenes (DNTs) and aminodinitrotoluenes (ADNTs), among other products, by microorganisms, light, and heat. These compounds have been measured by using HPLC or other instrumental analytical devices (Borch and Gerlach, 2004; Ahmad and Roberts; 1995). These instrumental analyses, however, require tedious pre-treatments such as extraction from samples (Halasz et al., 2002). On the other hand, detection methods using an antigen-antibody reaction, such as enzyme-linked immunosorbent assay (ELISA) and fluorescent and chemiluminescent

\footnotetext{
Laboratory of Food Analysis, Division of Food Biotechnology, Department of Bioscience and Biotechnology, Graduate School of Bioresource and Bioenvironmental Sciences, Kyushu University

${ }^{2}$ Graduate School of Information Science and Electrical Engineering, Kyushu University, Fukuoka, 819-0395, Japan

3 Art, Science and Technology Center for Cooperative Research, Kyushu University, Kasuga, Fukuoka, 816-8580, Japan

* Corresponding author (E-mail: kmatsu@agr.kyushu-u.ac.jp)
}

immunosensors, are more useful and are able to detect ppb levels of explosive compounds (Goldman et al., 2003; Green et al., 2002; Wilson et al., 2003).

We have been engaged in development of an antibody with high avidity to explosive-related compounds. In recent years, we have focused on the development of highly sensitive surface plasmon resonance (SPR) sensing methods for the detection of TNT using an antigenantibody reaction (Sakai et al., 2003; Shankaran et al., 2004; Shankaran et al., 2005a; Shankaran et al., 2005b; Matsumoto et al., 2005; Shankaran et al., 2006). According to the reports of Jenkins et al. (2000, 2001), the concentrations of 2,4-DNT and other decomposed nitroaromatic compounds around and over buried landmines are higher than the concentration of TNT.

In the present study, a polyclonal antibody against 2,4-DNT was raised in a rabbit, and the antibody was applied to the detection of 2,4-DNT using ELISA. The aim was to prepare anti-DNPh-KLH antibody from a rabbit and to clarify the characteristics for the detection of 2,4-DNT based on the principle of indirect competitive ELISA. In the course of the detection of free 2,4-DNT, we recognized that the combination of the structure of the coating antigen-protein, free 2,4-DNT, and the antiDNPh-KLH antibody are an important factor in sensitivity using an indirect competitive immunoassay. Therefore, the effect of the structures of the coating antigen-protein conjugates on the sensitivity of the detection of free 2,4-DNT was investigated in detail. 


\section{MATERIALS AND METHODS}

\section{Materials}

Bovine serum albumin (BSA), $p$-nitrophenyl phosphate disodium salt ( $p$-NPP), sodium sulfate, 2,4,6-trinitrobenzenesulfonate sodium salt (TNBS), 1,6-diaminohexane, 6-aminohexanoic acid, $N$-hydroxysuccinimide (NHS), and gelatin were obtained from Nacalai Tesque, Inc. (Kyoto, Japan). Ovalbumin (OVA), keyhole limpet hemocyanin (KLH), alkaline phosphatase (ALP)-labeled anti-rabbit IgG, 1-ethyl-3-(3-dimethyl aminopropyl) carbodiimide (EDC), hexylamine, ethylamine, 2,4-dinitrotoluene (2,4-DNT), and $N$-(2,4-dinitrophenyl) glycine (2,4-DNPh-gly) were obtained from Sigma (St. Louis, MO, USA). 2,4,6-Trinitrophenol (TNPh-OH) and 1,3-dinitrobenzene were purchased from Kishida Chemical Co., Ltd. (Osaka, Japan). 2,6-Dinitrotoluene (2,6-DNT), bis(2-methoxyethyl) ether, 1,2-diaminoethane, 1,4-diaminobutane, 1,8-diaminooctane, 1,10-diaminodecane, and 1,12-diaminododecane were obtained from Wako Pure Chemicals Ind., Ltd. (Osaka, Japan). $\quad N-(2,4,6$-trinitrophenyl) glycine (TNPh-gly) was obtained from Funakoshi Co. (Tokyo, Japan). 2,4-Dinitrobenzenesulfonate sodium salt (2,4-DNBS) was from Research Chemicals (Toronto, Canada). 2,4,6-Trinitrotoluene (TNT), 2-amino-4,6-dinitrotoluene (2-amino-4,6-DNT), and 4-amino-2,6-dinitrotoluene (4-amino-2,6-DNT) were purchased from Supelco (Bellefonte, PA, USA). Freund's complete adjuvant was obtained from Difco (Detroit, MI, USA). Rabbit (6 weeks old, female) was purchased from Kyoyu (Fukushima, Japan). The Hi Trap Protein G column and PD-10 column were purchased from Amersham Bioscience (Piscataway, NJ, USA). All other reagents were of analytical-reagent grade. All buffer solutions were prepared using water purified with a Milli-Q filter (Millipore, Bedford, MA, USA).

\section{Apparatus}

ELISA measurements were performed using 96-well immunoplates (NUNC, No. 446612, Roskilde, Denmark) and a microplate reader (Wallac 1420, Perkin Elmer Life Science Japan, Tokyo, Japan). Spectrophotometric measurements were performed using a Shimadzu Multi Spec 1500 (Kyoto, Japan).

\section{Preparation of DNPh-KLH}

2,4-DNBS (in $1 \mathrm{mg} \mathrm{mL}^{-1} \mathrm{H}_{2} \mathrm{O}, 1 \mathrm{~mL}$ ) was reacted with $1 \mathrm{~mL}$ of $0.48 \mathrm{~mol} \mathrm{~L}^{-1}$ (M) $\mathrm{NaHCO}_{3}$ solution ( $\mathrm{pH}$ 8.5) containing $10 \mathrm{mg} \mathrm{KLH}$ for $12 \mathrm{~h}$ at $40^{\circ} \mathrm{C}$. After the reaction, the preparation was dialyzed against five changes of $\mathrm{H}_{2} \mathrm{O}$ at $4{ }^{\circ} \mathrm{C}$ for 3 days, and then lyophilized to produce the DNPh-KLH conjugate. The molar ratios of the DNPh moieties to the protein were estimated using the molar adsorption coefficient of DNPh-NH- $\left(1.74 \times 10^{4} \mathrm{~cm}^{-1} \mathrm{M}^{-1}\right.$ at $360 \mathrm{~nm})$.

Preparation of coating antigen-protein conjugates DNPh-OVA: 2,4-DNBS (in $2 \mathrm{mg} \mathrm{mL}^{-1} \mathrm{H}_{2} \mathrm{O}, 1 \mathrm{~mL}$ ) was reacted with $1 \mathrm{~mL}$ of $25 \mathrm{mM}$ borate buffer ( $\mathrm{pH} 8.0$ ) con- taining $10 \mathrm{mg}$ OVA for $15 \mathrm{~h}$ at $40{ }^{\circ} \mathrm{C}$. After the reaction, the preparation was dialyzed against five changes of $\mathrm{H}_{2} \mathrm{O}$ at room temperature for 2 days, and then lyophilized to produce the DNPh-OVA-1 conjugate. The other five conjugates were prepared by the same procedures as DNPh-OVA-1 except for the concentration of 2,4-DNBS (DNPh-OVA-2: $10 \mathrm{mg} \mathrm{mL}^{-1}$; DNPh-OVA-3: $20 \mathrm{mg} \mathrm{mL}^{-1}$; DNPh-OVA-4: $40 \mathrm{mg} \mathrm{mL}^{-1}$; DNPh-OVA-5: $100 \mathrm{mg} \mathrm{mL}^{-1}$; DNPh-OVA-6: $200 \mathrm{mg} \mathrm{mL}^{-1}$ ).

DNPh-Cx-OVA: Six different DNPh-Cx-OVA conjugates with different length methylene chains (spacers) between the hapten and protein (OVA) were prepared. In a solution of $25 \mathrm{mM}$ borate buffer ( $\mathrm{pH} 8.0,1 \mathrm{~mL})$, $8.82 \mathrm{mg}$ of OVA and $2.18 \mathrm{mg}$ of NHS were dissolved, and then $52.9 \mathrm{mg}$ of EDC was added to the solution and stirred over night at room temperature. 1,2-Diaminoethane ( $0.51 \mathrm{mg}$, liquid) was gently added to the reaction mixture and stirred over-night. The mixture was dialyzed against three changes of $\mathrm{H}_{2} \mathrm{O}$ at room temperature and lyophilized to produce C2-OVA. After the lyophilized powder ( $2 \mathrm{mg}$ ) was dissolved in $1 \mathrm{ml}$ of $4 \% \mathrm{NaHCO}_{3}$ solution, $1 \mathrm{~mL}$ of 2,4-DNBS solution $\left(16 \mathrm{mg} \mathrm{mL}^{-1}\right)$ was added to the solution and stirred over-night at $40^{\circ} \mathrm{C}$. The reaction mixture was dialyzed against $\mathrm{H}_{2} \mathrm{O}$ and lyophilized to produce DNPh-C2-OVA conjugate. Other conjugates were prepared using the same procedures except for the concentrations of diaminoalkanes and 2,4-DNBS (DNPhC4-OVA: $0.78 \mathrm{mg}$ of 1,4-diaminobutane in $200 \mu \mathrm{L}$ DMSO, $16 \mathrm{mg} \mathrm{mL}^{-1}$ of 2,4-DNBS; DNPh-C6-OVA: $1.00 \mathrm{mg}$ of 1,6 -diaminohexane in $200 \mu \mathrm{L}$ DMSO, $16 \mathrm{mg} \mathrm{mL}^{-1}$ of 2,4-DNBS; DNPh-C8-OVA: $1.24 \mathrm{mg}$ of 1,8-diaminooctane in $200 \mu \mathrm{L}$ DMSO, $16 \mathrm{mg} \mathrm{mL}^{-1}$ of 2,4-DNBS; DNPhC10-OVA: $1.49 \mathrm{mg}$ of diaminodecane in $200 \mu \mathrm{L}$ DMSO, $5 \mathrm{mg} \mathrm{mL} \mathrm{mL}^{-1}$ of 2,4-DNBS; DNPh-C12-OVA: $1.49 \mathrm{mg}$ of 1,12 -diaminododecane in $200 \mu \mathrm{L}$ DMSO, $7 \mathrm{mg} \mathrm{mL}^{-1}$ of 2,4-DNBS).

DNPh-glycine-OVA: $25 \mathrm{mg}$ of DNPh-glycine and $13 \mathrm{mg}$ of NHS were dissolved in $1 \mathrm{~mL}$ of bis (2-methoxyethyl) ether. Fifty mg of sodium sulfate was added, and the mixture was cooled to $0{ }^{\circ} \mathrm{C}$. To the mixture was added $34 \mathrm{mg}$ of $\mathrm{EDC}$, and the reaction mixture was allowed to warm to room temperature and stirred overnight. Ten mg of OVA were dissolved in $1 \mathrm{~mL}$ of $25 \mathrm{mM}$ borate buffer ( $\mathrm{pH} 8.0$ ). At intervals of $30 \mathrm{~min}$, three aliquots of the NHS-ester solution (each $62 \mu \mathrm{L}$ ) were added slowly to the OVA solution under intense stirring. After reacting $2 \mathrm{~h}$, the mixture was passed through a PD 10 gel filtration column, and then the eluted fraction was lyophilize to produce DNPh-glycine-OVA conjugate (DNPh-gly-OVA).

\section{Synthesis of $\mathbf{T N P h}$-derivatives}

TNPh-derivatives were synthesized according to our previous report (Sakai et al., 2003).

\section{Immunization}

A rabbit was immunized with DNPh-KLH conjugate according to the following procedure. Conjugate dissolved in PBS (0.6 $\mathrm{mg} \mathrm{mL}^{-1}$ ) was emulsified with an equal volume of Freund's complete adjuvant. On days 0, 14 
28, 42 and 56, $1 \mathrm{~mL}$ of the prepared mixture was intracutaneously injected into the rabbit. On days 0, 35, 49 and 63 , the rabbit was bled from an ear vein, and the antiserum was collected by centrifugation of the blood sample. The antiserum was tested by direct enzyme-linked immunosorbent assay (direct-ELISA). Ninety-six-well immunoplates were coated with $100 \mu \mathrm{L}$ of DNPh-KLH conjugate $\left(10 \mu \mathrm{g} \mathrm{mL}^{-1}\right.$ in $50 \mathrm{mM}$ carbonate buffer, $\mathrm{pH}$ 9.6) over-night at room temperature. The plates were then washed three times with PBS containing 0.05\% Tween 20 (PBST), and treated with $150 \mu \mathrm{L}$ of $1 \%$ gelatin for $1 \mathrm{~h}$ at room temperature, and again washed three times with PBST and reacted with antiserum at eight different dilutions (1/1000 to $1 / 128000$ in PBS), which were added to the wells ( $50 \mu \mathrm{L}$ to each well) and incubated for $2 \mathrm{~h}$ at room temperature. The plates were washed again three times with PBST, and a solution of ALP-labeled antirabbit IgG (2000-fold dilution in PBS) was added (100 $\mu \mathrm{L}$ to each well) and incubated for $1 \mathrm{~h}$ at room temperature. The plates were washed again, and the substrate solution $\left(2 \mathrm{mg} \mathrm{mL} \mathrm{m}^{-1}\right.$ of $p-\mathrm{NPP}$ in $50 \mathrm{mM}$ carbonate buffer, $\mathrm{pH} 9.6$, containing $1 \mathrm{mM} \mathrm{MgCl}_{2}$ and $0.1 \mathrm{mM} \mathrm{ZnCl}_{2}$ ) was added and incubated for $30 \mathrm{~min}$ at room temperature. Then absorbance was measured at $405 \mathrm{~nm}$.

\section{Preparation and purification of polyclonal anti- DNPh-KLH antibody}

Whole blood of the rabbit was collected by cardiocentesis 7 days after the last injection. The purification was performed according to our previous paper (Sakai et al., 2003) with a minor modification.

\section{Indirect competitive ELISAs for 2,4-DNT}

ELISAs for 2,4-DNT were performed as follows. Ninety-six-well immunoplates were coated with $100 \mu \mathrm{L}$ of DNPh-OVA conjugates (DNPh-OVA-1 to DNPh-

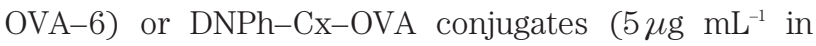
$50 \mathrm{mM}$ carbonate buffer, $\mathrm{pH}$ 9.8) over-night at room temperature. The following day, the plates were washed three times with PBST and treated with $150 \mu \mathrm{L}$ of $1 \%$ gelatin for $1 \mathrm{~h}$ at room temperature. The plates were washed three times with PBST and reacted with $100 \mu \mathrm{L}$ of the equivalent mixtures of anti-DNPh-KLH antibody $\left(2 \mu \mathrm{g} \mathrm{mL}^{-1}\right)$ and serially diluted DNPh-derivative antigen for $1 \mathrm{~h}$ at room temperature. The plates were washed three times with PBST, and then reacted with $100 \mu \mathrm{L}$ of ALP-labeled anti-rabbit IgG (2000-fold dilution in PBS) for $45 \mathrm{~min}$ at room temperature. After washing three times with PBST, $100 \mu \mathrm{L}$ of the substrate solution (2 mg $\mathrm{mL}^{-1}$ of $p-\mathrm{NPP}$ in $50 \mathrm{mM}$ carbonate buffer, $\mathrm{pH} 9.8$, containing $1 \mathrm{mM} \mathrm{MgCl}_{2}$ and $0.1 \mathrm{mM} \mathrm{ZnCl}_{2}$ ) was added to each well and incubated for $30 \mathrm{~min}$ at room temperature. The absorbance at $405 \mathrm{~nm}$ was measured using a microplate reader.

\section{Avidity of anti-DNPh-KLH antibody to various kinds of nitroaromatic compounds}

The avidity of anti-DNPh-KLH antibody to nitroaromatic compounds was investigated by indirect competitive ELISAs using the DNPh-gly-OVA conjugate and
DNPh-C8-OVA as a coating antigen-protein conjugate. The ELISA procedures were the same as described in the section of Indirect competitive ELISAs for 2,4-DNT. The $\mathrm{IC}_{50}$ was defined as the concentration of added DNPh derivative that yields 50\% inhibition compared with no inhibition (100\%). Molar cross-reactivities were related to 2,4-DNT (100); namely, all molar cross-reactivities were determined in relation to the 2,4-DNT standard inhibition curve. The molar cross-reactivity was calculated using the $\mathrm{IC}_{50}$ of each derivative according to the following equation (Weiler and Zenk, 1976):

$$
\mathrm{CR}=\left(\mathrm{IC}_{50} * / \mathrm{IC}_{50}\right) \times 100
$$

where $\mathrm{CR}$ is molar cross-reactivity [\%], $\mathrm{IC}_{50} *$ is the $\mathrm{IC}_{50}$ of the DNT standard $[\mathrm{M}]$, and $\mathrm{IC}_{50}$ is the $\mathrm{IC}_{50}$ of derivatives or related compounds $[\mathrm{M}]$.

\section{RESULTS AND DISCUSSION}

\section{Immunization efficacy}

The results of the immunization of the rabbit with DNPh-KLH conjugate are shown in Fig. 1. The antisera titers of the immunized rabbit increased, especially after booster immunization. The whole blood of the rabbit was collected at day 63. The concentration of the anti-DNPhKLH antibody after Protein G treatment was estimated to be about $5 \mathrm{mg} \mathrm{mL}^{-1}$ of serum, standardized as human IgG.

\section{Temperature dependence of avidity between anti- DNPh-KLH antibody and DNT}

Temperature dependencies of the avidity between the anti-DNPh-KLH antibody and 2,4-DNT was investigated by using indirect competitive-ELISA. DNPh-OVA $\left(0.01 \mu \mathrm{g} \mathrm{mL}^{-1}\right)$ was immobilized on the surface of the wells, and an antibody concentration of $10 \mu \mathrm{g} \mathrm{mL} \mathrm{m}^{-1}$ was used. Competitive reactions among free 2,4-DNT, bound DNPh-OVA, and anti-DNPh-KLH antibody were performed for $1 \mathrm{~h}$. The results are shown in Fig. 2. The sen-

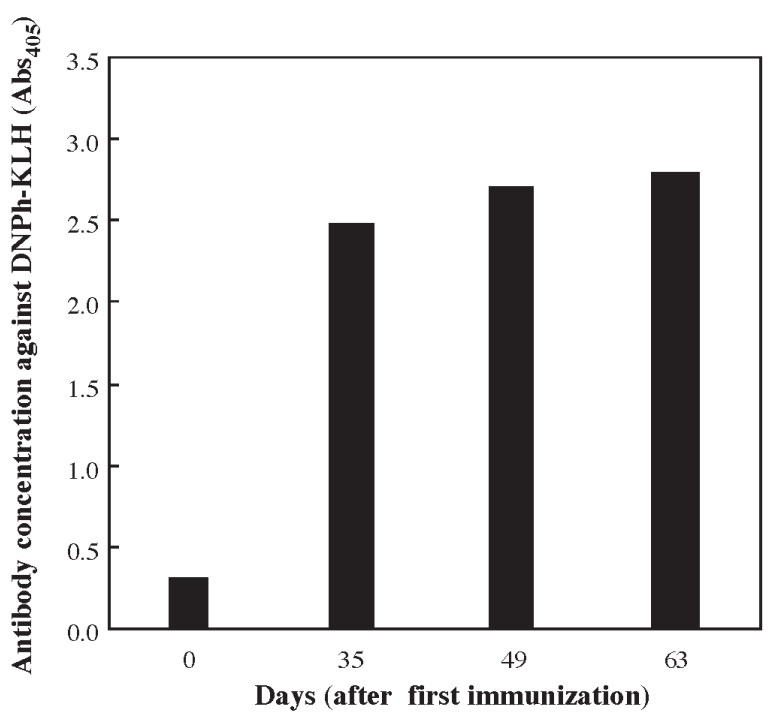

Fig. 1. Time course of antigen-specific antibody concentration in sera from a rabbit immunized with $\mathrm{DNPh}-\mathrm{KLH}$ conjugate. The data in the figure are shown using 16,000-fold diluted sera with PBS. 


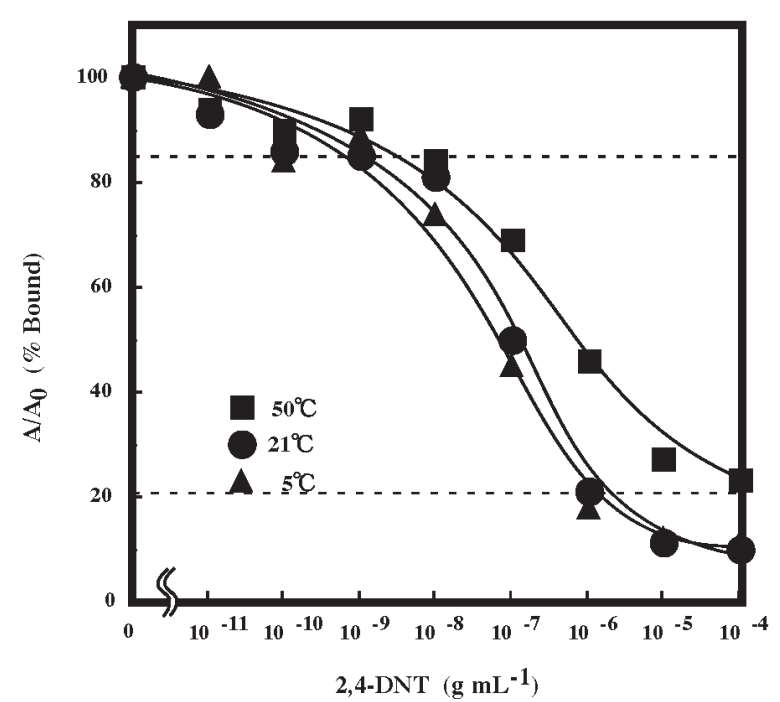

Fig. 2. Dependence on temperature of the avidity between antiDNPh-KLH antibody and 2,4-DNT measured by indirectELISAs. The concentrations of DNPh-OVA (coating antigen-protein conjugate) and anti-DNPh-KLH antibody were $0.01 \mu \mathrm{g} \mathrm{mL}^{-1}$ and $10 \mu \mathrm{g} \mathrm{mL}^{-1}$, respectively.

sitivity, or detection limit, of these analyses was defined as the concentration of antigen at which the percentage bound was depressed to $85 \%$. The concentrations for $15 \%$ inhibition were almost the same at different temperatures, but there was a tendency toward higher sensitivity at lower temperatures. At lower temperatures, the non-specific binding of the antibody will be depressed, but simultaneously, the signal intensities will be weakened. In this case, differences in sensitivity between the temperatures were hard to distinguish, probably because of the lower signal intensities and avidity. At higher temperatures, the sensitivity observed was lower, but even so, the antibody was usable up to $50^{\circ} \mathrm{C}$.

\section{Optimization of number of DNPh-groups intro- duced on coating antigen-protein conjugates}

To elucidate the effect of DNPh-group on the coating antigen-protein conjugate on the sensitivity, six DNPh-OVA conjugates having DNPh-groups of 0.4-5.3 mol per mol of OVA were examined. The OVA concentrations of the DNPh-groups were: DNPh-OVA-1 (0.4 mol per mol OVA), DNPh-OVA-2 (1.3 mol per mol OVA), DNPh-OVA-3 (2.7 mol per mol OVA), DNPh-OVA-4 (3.0 mol per mol OVA), DNPh-OVA-5 (5.0 mol per mol OVA), and DNPh-OVA-6 (5.3 mol per mol OVA). The DNPh-groups introduced on OVA were increased depending on the increased concentration of 2,4-DNBS, and the number was leveled off at more than $5 \%$ of 2,4-DNBS (final concentration). The results of indirect competitive ELISA using these coating antigen-protein conjugates are shown in Fig. 3. DNPh-OVA-5 and -6, having DNPh-group concentrations higher than 5 mol per mol OVA, did not show the association of free 2,4-DNT with antibody (no inhibition, random data), and others (DNPh-OVA-1 to -4) showed a decreased signal, depending on the concentration of free 2,4-DNT. From Fig. 3,

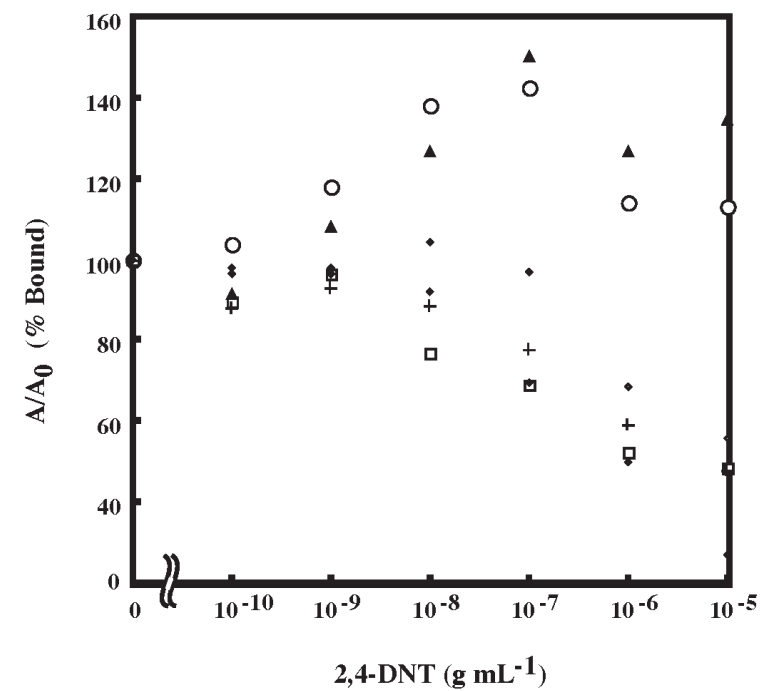

Fig. 3. Profiles of indirect competitive ELISA for 2,4-DNT using various DNPh-groups on the coating antigen-protein conjugates. Symbols are as follows: $\square$, DNPh-OVA-1; DNPh-OVA-2; +, DNPh-OVA-3; $\diamond$, DNPh-OVA-4; DNPh-OVA-5; $\boldsymbol{\Delta}$, DNPh-OVA-6.

the preferable coating antigen-protein conjugates were judged to be DNPh-OVA-1 to -3 , which have DNPhgroups at concentrations between 0.4 and $2.7 \mathrm{~mol}$ per mol OVA.

\section{Optimiztion of spacer length introduced on coat- ing DNPh-Cx-OVA conjugates}

The spacer length on the coating antigen-protein conjugates also affects the sensitivity of 2,4-DNT detection when using indirect-ELISA. DNPh-Cx-OVA conjugates with different length methylene chains (C2-C12) were synthesized. In this case, the number of DNPhgroups on the coating antigen-protein conjugates was restricted to 1-2 mol per mol OVA, judging from the previous results (Fig. 3). The results of indirect competitive ELISA are shown in Fig. 4. A decrease of signals due to the association between free 2,4-DNT and antibody was observed for all DNPh-Cx-OVA conjugates. The sensitivity evaluated as $\mathrm{IC}_{50}$ was improved with increasing spacer length up to C10. The preferable coating antigen-protein conjugates were judged to be DNPh-C8OVA or DNPh-C10-OVA. The improvement of the sensitivity was due to the following reasons: 1) the antibody could bind to the DNPh-moiety without the interference of a bulky protein-moiety of the coating antigen-protein conjugate, and 2) the antibody could recognize free 2,4-DNT and the DNPh-moiety equally because of the relatively long spacer. In general, recognition of a competitor by an antibody is reduced in heterologous systems. A small concentration of analyte, thus, will be sufficient to shift the equilibrium conditions against formation of the antibody-analyte immune complex, thereby inhibiting association of the antibody to the competitor and leading to very sensitive assays (Marco et al., 1995). On the other hand, Kim et al. (2003) reported that heterology in the spacer length of the coating antigen had 


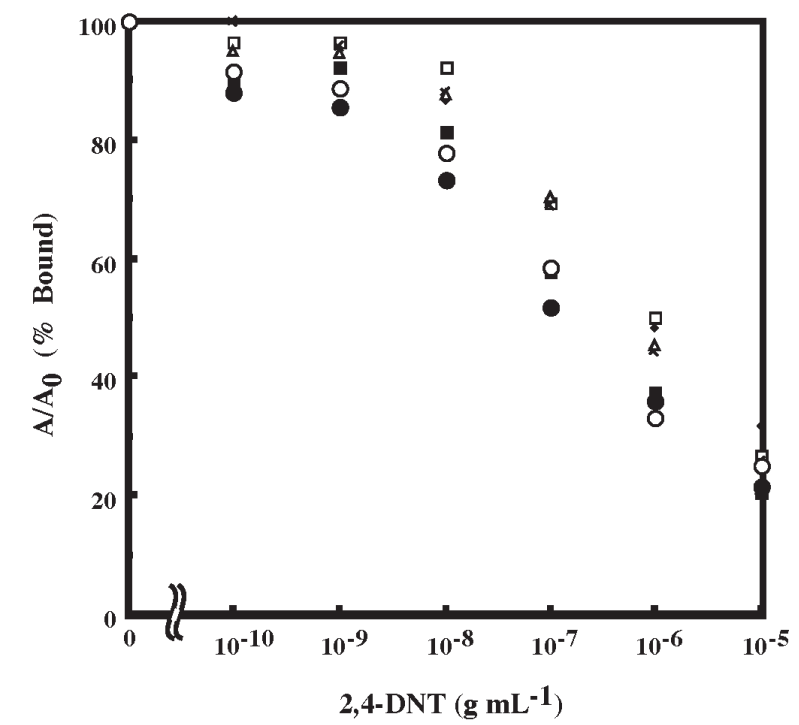

Fig. 4. Profiles of indirect competitive ELISA for 2,4-DNT using various lengths of spacers on the coating antigen-protein conjugates. Symbols are as follows: $\square$, DNPh-OVA; DNPh-C2-OVA; $\times$, DNPh-C4-OVA; $\triangle$, DNPh-C6-OVA; 口, DNPh-C8-OVA;, DNPh-C10-OVA; O, DNPh-C12OVA.

no significant effect on the sensitivity of ELISA, but heterology in the spacer structure of the coating antigen produced a remarkable improvement in the sensitivity of ELISA. Although the spacer structure was not examined in our experiment, the spacer length of the coating antigen-protein conjugate also affected the sensitivity of
ELISA in our case

\section{Avidity of anti-DNPh antibody to various kinds of nitroaromatic compounds}

The avidity of the raised antibody to nitroaromatic compounds was evaluated by indirect competitive ELISAs. Two coating antigen-protein conjugates were used in this experiment: DNPh-C8-OVA and DNPh-glyOVA. Midpoints $\left(\mathrm{IC}_{50}\right)$ and molar cross-reactivities are listed in Table 1. On using DNPh-C8-OVA, 2,6-DNT and 4-amino-2,6-DNT showed cross-reactivity of less than $1 \%$ or no association, when the molar cross-reactivity of 2,4-DNT was set as $100 \%$. These results show that the anti-DNPh-KLH antibody recognized the nitro group of the 4-position of the benzene ring. 2-Amino-4,6-DNT showed about $3 \%$ molar cross-reactivity due to the amino group at the 2-position. TNPh-derivatives showed about 4-5\% molar cross-reactivity or no association except to TNPh-amine (TNA). The anti-DNPh-KLH antibody seemed to discriminate between dinitrophenyland trinitrophenyl-compounds. On the other hand, 2,4-DNPh-glycine and TNPh-amine (TNA) showed high molar cross-reactivity, especially to 2,4-DNPh-glycine $(>900 \%)$. These results indicate that the anti-DNPh$\mathrm{KLH}$ antibody recognizes these compounds as an antigen. These phenomena occur because the dinitrophenyl moiety of the immunogen (2,4-DNPh-KLH conjugate) binds to KLH via an NH group and the antibody also recognizes the $\mathrm{NH}$ moiety of the 1-position of the benzene ring. 1,3-DNB showed molar cross-reactivity of about $5 \%$ because of the meta position of nitro groups.

Table 1. Avidity of anti-DNPh-KLH antibody to the nitroaromatic compounds

\begin{tabular}{|c|c|c|c|c|c|}
\hline \multirow{2}{*}{$\begin{array}{l}\text { Nitroaromatic } \\
\text { compounds }\end{array}$} & \multirow{2}{*}{ M.W. } & \multicolumn{2}{|c|}{$\begin{array}{l}\text { Coating antigen-protein } \\
\text { DNPh-C8-OVA }\end{array}$} & \multicolumn{2}{|c|}{$\begin{array}{l}\text { Coating antigen-protein } \\
\text { DNPh-gly-OVA }\end{array}$} \\
\hline & & $\mathrm{IC}_{50}(\mathrm{M})$ & $\begin{array}{c}\text { Molar cross-reactivity } \\
(\%)\end{array}$ & $\mathrm{IC}_{50}(\mathrm{M})$ & $\begin{array}{c}\text { Molar cross-reactivity } \\
\text { (\%) }\end{array}$ \\
\hline $\begin{array}{l}\text { 2, 4-dinitrotoluene } \\
(2,4 \text {-DNT })\end{array}$ & 182 & $1.4 \times 10^{-7}$ & 100 & $4.9 \times 10^{-7}$ & 100 \\
\hline $\begin{array}{l}2,6 \text {-dinitrotoluene } \\
(2,6 \text {-DNT })\end{array}$ & 182 & $3.4 \times 10^{-5}$ & 0.4 & $5.5 \times 10^{-5}$ & 0.9 \\
\hline $\begin{array}{c}\text { 2-amino-4, 6-dinitrotoluene } \\
\text { (2-ADNT) }\end{array}$ & 197 & $5.1 \times 10^{-6}$ & 2.7 & $2.5 \times 10^{-6}$ & 19.5 \\
\hline $\begin{array}{c}\text { 4-amino-2, 6-dinitrotoluene } \\
\text { (4-ADNT) }\end{array}$ & 197 & N.I.* & - & N.I.* & - \\
\hline $\begin{array}{c}\text { 2, 4-dinitrophenylglycine } \\
\text { (2,4-DNP-gly) }\end{array}$ & 241 & $1.5 \times 10^{-8}$ & 933 & $2.9 \times 10^{-8}$ & 1700 \\
\hline $\begin{array}{c}\text { 1,3-dinitrobenzene } \\
(1,3-\mathrm{DNB})\end{array}$ & 168 & $3.0 \times 10^{-6}$ & 4.7 & $2.7 \times 10^{-6}$ & 18.1 \\
\hline Trinitrophenol(TNP) & 227 & $3.1 \times 10^{-6}$ & 4.5 & $1.3 \times 10^{-6}$ & 37.7 \\
\hline $\begin{array}{c}\text { 2, 4, 6-trinitroaniline } \\
\text { (TNA) }\end{array}$ & 228 & $1.3 \times 10^{-7}$ & 107.7 & $1.3 \times 10^{-7}$ & 375 \\
\hline $\begin{array}{c}N-(2,4,6-\text { trinitrophenyl)- } \\
\text { hexylamine (TNP-ha) }\end{array}$ & 312 & N.I. $*$ & - & $2.9 \times 10^{-5}$ & 1.7 \\
\hline $\begin{array}{c}N-(2,4,6 \text {-trinitrophenyl)- } \\
\text { ethylamine (TNP-ea) }\end{array}$ & 284 & $3.2 \times 10^{-6}$ & 4.4 & $7.8 \times 10^{-7}$ & 63.3 \\
\hline $\begin{array}{c}N-(2,4,6 \text {-trinitrophenyl)- } \\
\text { glycine (TNP-gly) }\end{array}$ & 286 & $3.5 \times 10^{-6}$ & 4.0 & $7.0 \times 10^{-7}$ & 70.7 \\
\hline Trinitrotoluene (TNT) & 227 & N.I.* & - & $1.7 \times 10^{-6}$ & 28.1 \\
\hline
\end{tabular}

N.I.* ; not inhibited. Concentration-dependent inhibition was not observed in the range of the analyte concentrations studied $\left(1.0 \times 10^{-10}\right.$ $\left.-1.0 \times 10^{-5} \mathrm{~g} \mathrm{~mL}^{-1}\right)$. 
As shown in Table 1, the molar cross-reactivities and $\mathrm{IC}_{50} \mathrm{~s}$ showed different profiles when DNPh-gly-OVA was used as a coating antigen-protein conjugate. The selectivity for 2,4-DNT of DNPh-C8-OVA was much better than that of DNPh-gly-OVA. Optimization of a coating antigen-protein conjugate is an important factor for measurement by indirect competitive ELISA.

\section{Detection of 2,4-DNT by indirect competitive ELISA}

Figure 5 shows the standard curves of inhibition by 2,4-DNT using the anti-DNPh-KLH antibody and DNPhC8-OVA as a coating antigen-protein conjugate in indirect competitive ELISA. As shown in Fig. 5, 2,4-DNT was detected at the concentration of $1 \mathrm{ng} \mathrm{mL}^{-1}$ (more than $15 \%$ decrease). Dynamic ranges, defined by the analyte concentrations that inhibited maximum signals by $15 \%$ and $80 \%$, comprised a concentration range between $1 \mathrm{ng}$ $\mathrm{mL}^{-1}$ and $10 \mu \mathrm{g} \mathrm{mL}^{-1}$.

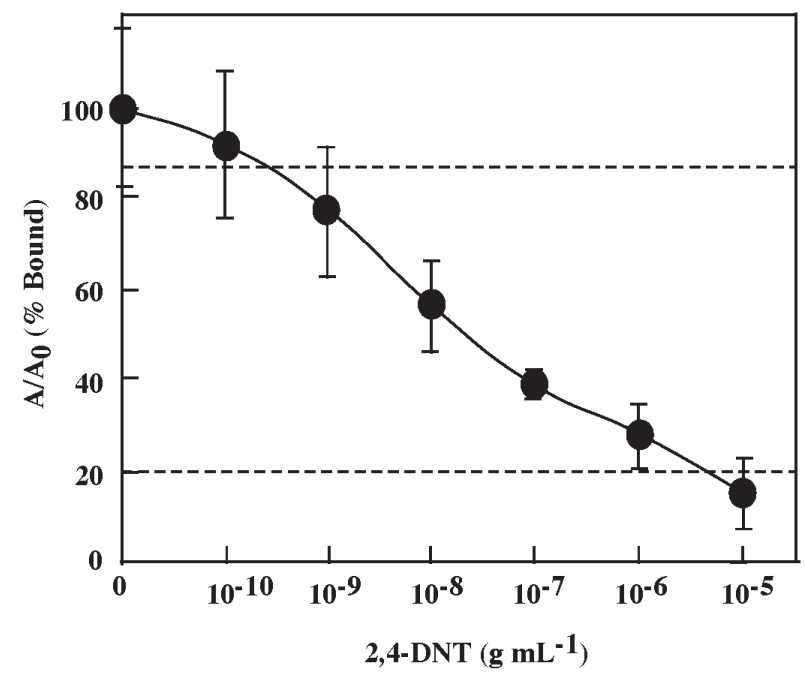

Fig. 5. Standard curve of 2,4-DNT in indirect competitive ELISA. The error bars show SD of five measurements. The concentrations of coating antigen-protein conjugate (DNPhC8-OVA) and the antibody (anti-DNPh-KLH antibody)

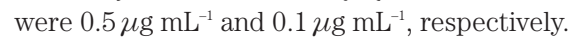

\section{Evaluation of affinity constant between free 2,4-DNT and anti-DNPh-KLH antibody}

Determination of an affinity constant, $\mathrm{K}_{\mathrm{A}}$, or its reciprocal, the dissociation constant, $\mathrm{K}_{\mathrm{D}}$, is frequently useful in the study of antigen-antibody interactions. Evaluation of $\mathrm{K}_{\mathrm{D}}$, however, is a difficult process because of the different values obtained by the method used for analysis. A convenient method developed by Seligman is widely used for calculating the $\mathrm{K}_{\mathrm{D}}$-value using indirect competitive ELISAs (Seligman, 1994). The basic equation is:

$\mathrm{a}_{0} / \mathrm{f}=\mathrm{K}_{\mathrm{D}} /(1-\mathrm{f})+\mathrm{i}_{0}$

Here, $f$ is the square root of $\left(A_{0}-A_{i}\right) / A_{0}\left(A_{i}\right.$ and $A_{0}$ are the absorbance with and without a competing antigen, respectively), and $\mathrm{a}_{0}$ and $\mathrm{i}_{0}$ stand for the initial concentration of the competing antigen (free analyte) and the initial antibody concentration, respectively. We evaluated the $\mathrm{K}_{\mathrm{D}}$-value with the inhibition curve of 2,4-DNT obtained in indirect competitive ELISA using Seligman's method. First, we evaluated the KD from the data shown in Fig. 3, which used DNPh-OVA-1 to -4 as coating antigen-protein conjugates. As expected from the data shown in Fig. 3, the dissociation constants between free 2,4-DNT and antibody were different, depending on the number of DNPh-groups on the coating antigen-protein conjugates. The evaluated values were $0.4 \times 10^{-5}$ $1.4 \times 10^{-5} \mathrm{M}\left(\mathrm{K}_{\mathrm{A}}=0.7 \times 10^{5}-2.5 \times 10^{5} \mathrm{M}^{-1}\right)$. The $\mathrm{K}_{\mathrm{D}}$ value was also evaluated by the data from Fig. 4 , which used DNPhC8-OVA as a coating antigen-protein conjugate. The calculated value was $0.2 \times 10^{-5} \mathrm{M}\left(\mathrm{K}_{\mathrm{A}}=5.0 \times 10^{5} \mathrm{M}^{-1}\right)$. This means that the association of the antibody with the coating antigen-protein conjugate was reduced and the association of the antibody with free 2,4-DNT was increased, improving the sensitivity of detection.

\section{CONCLUSIONS}

A polyclonal antibody against 2,4-DNT was successfully raised in a rabbit. The antibody was applied to detect 2,4-DNT by using indirect competitive ELISA. The measuring temperature scarcely affected on the detection sensitivity. The optimum coating antigen-protein conjugate on the microtiter plate was dinitrophenylC8-ovalbumin (DNPh-C8-OVA). The association constant between free 2,4-DNT and anti-DNPh-KLH antibody was $5.0 \times 10^{5} \mathrm{M}^{-1}$, when DNPh-C8-OVA was used as a coating antigen-protein conjugate. The immunoassay exhibited excellent sensitivity for the detection of $2,4-\mathrm{DNT}$ in the concentration range of $1 \mathrm{ng} \mathrm{mL}^{-1}$ to $10 \mu \mathrm{g}$ $\mathrm{mL}^{-1}$. The combination of the anti-DNPh-KLH antibody and DNPh-C8-OVA as a coating antigen-protein conjugate is useful for the detection of 2,4-DNT.

\section{ACKNOWLEDGEMENTS}

This work was partly supported by a Grand-in-Aid from JST (Japan Science and Technology Corporation).

\section{REFERENCES}

Ahmad F., and D. J. Roberts 1995 Use of narrow-bore high-performance liquid chromatography-diode array detection for the analysis of intermediates of the biological degradation of 2,4,6-trinitrotoluene. J. Chromatogr. A, 693: 167-175

Banerjee H. N., M. Verma, L. H. Hou, M. Ashraf, and S. K. Dutta 1999 Cytotoxicity of TNT and its metabolites. Yale J. Biol. Med., 72: 1-4

Borch T., and R. Gerlach 2004 Use of reversed-phase high-performance liquid chromatography-diode array detection for complete separation of 2,4,6-trinitrotoluene metabolites and EPA Method 8330 explosives: influence of temperature and ion-pair reagent. J. Chromatogr. A, 1022: 83-94

Goldman E. R., A. Hayhurst, B. M. Lingerfelt, B. L. Iverson, G. Georgiou, and G. P. Anderson 2003 2,4,6-Trinitrotoluene detection using recombinant antibodies. J. Environ. Monit. 5: $380-383$

Green T. M., P. T. Charles, and G. P. Anderson 2002 Detection of 2,4,6-trinitrotoluene in sea water using a reversed-displacement immunosensor. Anal. Biochem., 310: 36-41

Halasz A., C. Groom, E. Zhou, L. Paquet, C. Beaulier, S. Deschamps, A. Corrveau, S. Thiboutot, G. Ampleman, C. Dubois, and J. 
Hawari 2002 Detection of explosives and their degradation products in soil envieronments. J. Chromatogr. A, 963: 411-418

Hilmi A., J. H. T. Luong, and A. L. Nguyen 1999 Determination of explosives in soil and ground water by liquid chromatography-amperometric detection. J. Chromatogr. A, 844: $97-110$

Jenkins T. F., M. E. Walsh, P. H. Miyares, J. A. Kopczyuski, T. A. Ranney, V. George, J. C. Pennington, and T. E. Berry Jr., 2000 "Cold Regions Research and Engineering Laboratory, Technical Report ERDC TR-00-5, August 2000"

Jenkins T. F., D. C. Leggett, P. H. Miyares, H. E. Walsh, T. T. Ranney, J. H. Cragin, and V. George 2001 Chemical signature of TNT-filled landmines. Talanta, 54: 501-503

Kennel S. J., L. J. Foote, M. Morris, A. A. Vass, and W. H. Griest 2000 Mutation analyses of series of TNT-related compounds using the CHO-hprt assay. J. Appl. Toxicol., 20: 441-448

Kim Y. J., Y. A. Cho, H-S. Lee, Y. T. Lee, S. T. Gee, and B. D. Hammock 2003 Immunoassay of organophosphorous pesticides and effect of heterology in hapten spacer arm length on immunoassay sensitivity. Anal. Chim. Acta, 475: 85-96

Marco M-P., S. Gee, and B. D. Hammmock 1995 Immunochemical techniques for environmental analysis II. Antibody production and immunoassay developments. Trends Anal. Chem., 14: $415-425$

Matsumoto K., A. Torimaru, S. Ishitobi, T. Sakai, H. Ishikawa, K. Toko, N. Miura, and T. Imato 2005 Preparation and characterization of a polyclonal antibody from rabbit for detection of trinitrotoluene by a surface plasmon resonance biosensor. Talanta, 68: 305-311

Sakai T., A. Torimaru, K. Shinahara, N. Miura, T. Imato, K. Toko, and K. Matsumoto 2003 Preparation of a Polyclonal Antibody and a Bioassay for Nitroaromatic Compounds by an Enzyme-Linked Immunosorbent Assay Technique and a Surface Plasmon Resonance Immunosensor. Sens. Mater. 15: $439-452$

Sayama M., M. Mori, M. Shoji, S. Uda, M. Kakikawa, T. Kondo, and
K. Kodaira 1998 Mutagenicities of 2,4- and 2,6-dinitrotoluenes and their reduced products in Salmonella typhimurium nitroreductase- and $O$-acetyltransferase- overproducing Ames test strains. Mutat. Res., 420: 27-32

Seligman S. T. 1994 Influence of solid-phase antigen in competition enzyme-linked immunosorbent assays (ELISAs) on calculated antigen-antibody dissociation constants. $J$. Immunol. Methods, 168: 101-110

Shankaran D. R., K. V. Gobi, K. Matsumoto, T. Imato, K. Toko, and N. Miura 2004 Highly sensitive surface plasmon resonance immunosensor for parts-per-trillion level detection of 2,4,6-trinitrophenol. Sens. Act. B, 100: 450-454

Shankaran D. R., K. V. Gobi, T. Sakai, K. Matsumoto, K. Toko, and N. Miura 2005a Surface plasmon resonance immunosensor for highly sensitive detection of 2,4,6-trinitrotoluene. Biosens. Bioelectron., 20: 1750-1756

Shankaran D. R., K. V. Gobi, T. Sakai, K. Matsumoto, T. Imato, K. Toko, and N. Miura 2005b A novel surface plasmon resonance immunosensor for 2,4,6-trinitrotoluene (TNT) based on indirect competitive immunoreaction: a promising approach for on-site ladmine detection. IEEE Sens. J., 5 616-621

Shankaran D. R., K. Matsumoto, K. Toko, and N. Miura 2006 Devepment and comparison of two immunoassays for the detection of 2,4,6-trinitrotoluene (TNT) based on surface plasmon resonance. Sens. Act. B, 114: 71-79

Tchounwou P. B., B. A. Wilson, A. B. Ishaque, and J. Schneider 2001 Transcriptional activation of stress genes and cytotoxicity in human liver carcinoma cells (HepG2) exposed to 2,4,6-trinitrotoluene, 2,4-dinitrotoluene, and 2,6-dinitrotoluene. Environ. Toxicol., 16: 209-216

Weiler E. W., and M. H. Zenk 1976 Radioimmunoassay for the determination of digoxin and related compounds in Digitalis lanata. Phytochem., 15: 1537-1545

Wilson R., C. Clavering, and A. Hutchinson 2003 Electrochemiluminescence enzyme immunoassay for TNT. Analyst, 128: 480-485 